\title{
Ideological Hegemony and Global Governance
}

\author{
by \\ Thomas Ford Brown \\ Sociology Department \\ Johns Hopkins University \\ Baltimore, MD 21218 USA \\ tombrown@jhunix.hcf.jhu.edu
}

Cite: Brown, Thomas Ford. (1997). "Ideological Hegemony and Global Governance." Journal of World-Systems Research 3: 250 - 258.

\section{Thomas Ford Brown}

In After Liberalism, Wallerstein argues that liberalism is in decline, both as a system and as a hegemonic discourse (Wallerstein, 1995). He holds that those dissatisfied with the liberal consensus have, since 1989 , turned to free-market rhetoric as an alternative, but he dismisses this movement as not "serious" (242). He holds that since the collapse of Communism, no hope for liberation remains that can tame the world's working class, and that liberalism cannot consequently survive.

I would argue that free-market ideology is more potent than Wallerstein allows, and that laissez-faire libertarian utopianism could conceivably prove as seductive to a disillusioned working class as socialist utopianism was during the early 20 th century. Libertarian sympathies and ideology are easily exploited by non-believers as a means of extending the status quo. "Minarchist" rhetoric upholding small government is commonly appropriated by politicians who have no intention of implementing a full libertarian program. The writings of Hayek and Nozick lend an aura of intellectual respectability to expedient "down-sizing" measures. The more strident, emotional writings of Ayn Rand and the other libertarian popularizers speak to a falling middle-class, telling them that the poor deserve their fate, that taxation for welfare and other unpopular government programs constitutes theft, and that selfishness is a virtue. Such distractions could conceivably succeed in the short run, which in world-historical time could last generations.

In this paper, I speak to "libertarianism" as it is understood in the United States: as a fiscally conservative and socially liberal political philosophy that upholds individual liberties and individual property rights above all other ideals. As such, libertarianism functions as the philosophical justification for Chicago school economic policy--for, in addition to the economic argument in favor of efficiency, libertarian philosophy adds a moral dimension that idealizes individualistic, instrumentally rational maximizing. Keynsianism can consequently be dismissed not only on technical grounds, but can also be indicted as morally corrupt. 
[Page 250]

Joumal of World-Systems Research

In this paper, I analyze libertarian discourse from the perspective of regulation theory, as a hegemonic ideology that underlies the emergence of a new mode of regulation. Within this general theoretical approach, I will also employ frames from regime theory as developed by international relations scholars, as well as the "epistemic community" approach from the same discipline. I want to suggest that free-market ideology could engender the emergence of rationalized global gove rnance in order to maintain a free trade, property rights, and other regulatory concerns of the emerging mode of accumulation, and that such a world state could conceivably extend liberalism's life by carrying liberalism to its extreme.

The regulation school posits two primary spheres of analysis in the study of political economy--the "regime of accumulation", and the "mode of regulation". The regime of accumulation is defined by a relatively stable and reproducible relationship between production and consumption (Hirst \& Zeitlin, 1992: 85). The mode of regulation is a complex of norms, institutions, organizational forms, social networks, and patterns of conduct that promote the reproducibility of the regime of accumulation (Jessop, 1992: $48)$.

Regulation theorists believe that the current regime of accumulation is in the process of transforming from a generally "Fordist" system into what Harvey has called "flexible accumulation" [1] (Harvey, 1990). Fordism is characterized by a circular relationship between mass production and mass consumption, with the main elements of the system generally confined within the borders of a nation-state (Jessop, 1992: 49). While theoretical conceptions of a post-Fordist regime differ, most analysts agree that new means of organizing production and consumption are beginning to appear that differ significantly from the Fordist paradigm. One of the most striking differences of the emergent regime is an increase in production, marketing, and accumulation on a global scale that ignores national boundaries whenever convenient. Although globalized economic action has long been a characteristic of the capitalist world-system, its intensification increases the need for regulation at the world level of governance.

While the mode of regulation associated with Fordist accumulation found its power base in a coalition between a nationalist state and nationally oriented capitalists, the fundamentally different character of flexible accumulation will require the corresponding rise of a new mode of regulation in order to sustain a period of economic and technological growth (Hirst, 1992: 85). Since flexible accumulation is globally realized, we might look for the new mode of regulation to appear on a global scale as well. Let's consider the role of global trade institutions and regional free trade alliances within the paradigm provided by regulation theory, and consider the role these institutions play within the mode of regulation. 
[Page 251]

Joumal of World-Systems Research

Do these international institutions constitute the beginning of a new, global mode of regulation? Questions of power pervade this discussion. Under the Fordist system, the individual state is ceded most of the power to regulate the economy and the social structures that functionally support the economy. Yet the intensification of a globalized economy suggests an increasing need for a globalized mode of regulation. While states participate in international negotiations by definition, they clearly can no longer wield such substantial control over their national economies as was possible in the past. The context of multilateral decision-making and an increasingly globalized financial system imposes growing limitations on the ability of a state to unilaterally control its own economy.

Further, just as political interest groups affect the outcome of national political processes, so do globally organized non-governmental interest groups affect international decisionmaking. In some instances, representatives of industrial trade organizations--or even representatives of specific firms--take part in international negotiations. International relations theorists have noted the appearance of global "epistemic communities" surrounding specific issue spaces (Haas, 1992). I will examine the role of epistemic communities in the last GATT preceding the formation of the WTO, considered in their role as a challenge to nationally sovereign regulation.

\section{Epistemic Communities}

Haas notes that the ways that government decision-makers define state interests and formulate policies to deal with complex technical issues can be influenced significantly according to how the issue is presented to them by specialists in that domain (Haas, 1992). The "epistemic community" approach describes the roles played by net works of experts in international decision-making: how they agree upon and articulate causal linkages within complex issue spaces; how they frame issues and define salient discourse; how they define and limit potential solutions or outcomes; and how they define state interests within the issue space.

The consideration of epistemic communities is relevant to the consideration of a global mode of regulation in that these communities are defined by issue space and by technical expertise rather than by national political dynamics. As technical knowledge disseminates and links specialists across political boundaries, we see the formation of knowledgebased power networks on a global scale [2]. I am speculating that this development presages the evolution of a technocracy that identifies with specific, focused issues and specialized knowledge rather than with more general national interests. It seems to me that a globally- identifying conglomeration of technocratic networks would be requisite to the functioning of an institutionalized global mode of regulation. 
[Page 252]

Joumal of World-Systems Research

\section{Gatt Negotiations: Trade In Services}

One significant development in the Uruguay Round involved the attempt to construct a new regime for international trade in services [3]. When the question of trade in services first arose, most governments did not understand the significance of the issue, and consequently had no idea of how a multilateral agreement could affect their policy decisions (Drake \& Nicolaidis, 1992).

On first gloss, liberalization in services could appear contrary to national interests-particularly as defined by domestic service providers. Further, services have traditionally been under heavy regulatory control by states for centuries. Hence existing social ontology mitigated against the implementation of a liberalized global regime in trade in services.

However, services function not only as outputs in their own right, but as vital inputs to a wide range of corporate activity. Consequently, liberalization of services could potentially reduce corporate costs and thus boost profitability. Further, many business services are global in nature, and impact upon market structures across borders. For example, the global provision of telecommunications, manage ment consulting, and financial services is crucial to multinational production and consumption. Hence a natural constituency exists among domestic MNCs in favor of liberalization, and an epistemic community consequently began to emerge around the issue.

One interesting feature of this particular epistemic community is that it did not exist long prior to the debate. In fact, it appears that once the core group had been able to place the issue on the agenda of various governments, state demand for more expert ise and information stimulated the growth of the community. The community's membership is organized in two categories. The first includes personnel from governments, international agencies, and private firms--in other words, people with a compelling interest in the outcome of the debate. The second group is comprised of people with a more purely intellectual interest in the issues: academics, lawyers, industry specialist, and journalists. Still, this second group could also potentially benefit materially from government decisions. Yet in their putative role as "objective" experts, they lend an aura of legitimacy to the former group. Since it is clear that liberalization has distributional consequences, the appearance of "scientific objectivity" was crucial in order to legitimate and justify the regime.

[Page 253]

Journal of World-Systems Research 
The community's influence dynamics are temporally variable, and fall into two categories: influence within the community itself, and influence by the community upon policy makers. Internally, the terms of discourse were set by predominantly AngloAmerican analysts who first posed the issues (Drake \& Nicolaidis, 1992: 40). By defining service transactions as "trade", they were able to evoke all of the normative assumptions surrounding the notion of "free trade". Those opposed to liberalization consequently were placed in the position of defending "protectionism".

Drake has four main points to make that describe the community's external influence:

1. First, in issues involving complexity and uncertainty, governments turn to expert communities for guidance and ideas. The newness of the notion of a trade in services regime created a fluidity around the issue space, providing an opportunity structure in which the new community could wield significant power. The situation also created a demand on the part of the governments for such input.

2. Second, to be influential, an epistemic community must have access to top policymakers. The community must establish both formal and informal channels, and further must create a body of thought that can "filter to them indirectly" (Drake \& Nicolaidis, 1992: 41).

3. Third, another function of an epistemic community is to frame issues and delimit the range of defensible policy options. In the case of the service community, it was necessary to create an analysis that could bridge the gap between governments' prior interest and policy structures and the new, politically untested issue of services.

4. Fourth, an epistemic community's influence tends to decline once the issue has reached the negotiating stage. By this point, ideas and interests are clearly delineated in the minds of policy-makers, and they no longer are as dependent upon the intellectual community. Consequently, second-tier members virtually dropped out of the picture in the services case. By the time of negotiations, power and bargaining dynamics increasingly determine policy selection and modification.

\section{Cohesion Vs. Domination Within Epistemic Communities}

It should be clear by now that regime theory and the epistemic community approach place an emphasis upon communities of actors. Incorporating these approaches into a regulationist analysis involves a different, conflicting set of assumptions than those upon 
which a regime/community approach is founded. The regulation school evolves from structural Marxism, retaining a good deal of structuralism. It also retains the fundamental Marxist world-view in which politics and economics are seen as intertwined and always contestable and contested.

However, the regime/epistemic community approaches emphasize community by definition, and consequently encourage us to view the "community" as benevolent, voluntary, cooperative, and fundamentally legitimate (Keeley, 1990: 90). Hence incorporating this approach with regulation theory requires us to reemphasize the conflictual and contestable nature of these policy debates, and to question exactly whose community is involved, and whose community benefits from its actions. Further, we need to integrate the cognitive construction of community/regime with the structural preoccupations of regulation theory.

One approach to this integration is through Foucault's notion of hegemonic discourse. For Foucault, a "discourse" is a statement connected to a social practice. These statements define a phenomenon, provide means and grounds for analyzing it, and suggest lines of action in terms of both ends and means. A hegemonic discourse constructs a "regime of truth", which evaluates statements according to their "truthfulness", and decides whether or not they are meaningful or nonsensical. The hegemonic discourse dominates, covers up, and discredits what Foucault terms "subjugated knowledges" (Keeley, 1990: 91). So a regime of truth goes further than agenda setting--it defines and endorses acceptable language, symbols, modes of reasoning, and conclusions.

The concepts of hegemonic discourse and subjugated knowledge point up the structural contestability of regimes. It becomes apparent that the community is not inherently voluntary and cooperative. Rather, it suggests that certain members of the community may wield more discursive power than other members, and that there is a structurally determined domination in play.

[Page 255]

Journal of World-Systems Research

We can also borrow Foucault's notion of "disciplines", which are means of implementing an analysis and giving it a social reality. They attempt to cause certain normative behaviors. Means are constructed to define and correct deviant behaviors. We might interpret a regime as a set of discourses and disciplines that give a specific order to a public issue space, and that authoritatively define the situation. It serves to politicize its realm by identifying public interest, by defining appropriate actions for participants, and by ordering and defining their relations (Keeley, 1990: 92).

A Foucauldian analysis, then, might consider transnational epistemic policy communities as a social means of constructing discourse and disciplines that promote the interests of the community. The Foucauldian perspective implies that an epistemic community's 
power extends beyond the Weberian definition of power--the ability to compel others towards one's own ends--into the discursive realm. Epistemic communities wield power by setting agendas, defining problems, and legitimizing desired solutions to those problems. Rather than compelling others, epistemic communities more likely serve to limit the power of opponents by discrediting their definition of the situation, and by discrediting their solutions. The Foucauldian perspective refines and extends the Gramscian conception of ideological hegemony, and can help us understand the role of ideology in international policy decisions.

Combining regulation theory with the IR notion of epistemic communities and a Foucauldian/Gramscian conception of ideological hegemony seems to me a good starting point for understanding the emergence of a world state. I have shown how free-market ideals dominate one epistemic community to influence regulation at the world level. I believe that this is generally true of most transnational epistemic communities that cannot be defined as antisystemic.

\section{Conclusion}

I have speculated that this example presages the evolution of a technocracy that identifies with specific, focused issues and specialized knowledge rather than with more general national interests. A globally-identifying conglomeration of such technocratic networks would be requisite to the functioning of an institutionalized global mode of regulation. It seems not unlikely, given recent developments in GATT, WTO, NAFTA, and other international negotiations, that libertarian-style privileging of free markets and individual property rights will increasingly dominate the emerging globalized, technocratic network of epistemic communities.

[Page 256]

Journal of World-Systems Research

There are other global epistemic communities that do not fit this description, most notably the Green movement and related environmental activism. But anti-systemic, antiliberal epistemic communities are more notable by their absence from the world stage. By anti-systemic, I mean any form of opposition to the free-market juggernaut--labor, nationalist, socialist/communist, or Green. Such movements, when they do manage some degree of trans-national organization, tend to focus on restricted issue spaces rather than more comprehensive programs of dissent.

World-wide labor movements have not been significant. Resistance to globalized liberalization has so far manifested more effectively from nationalist political actors than from opponents of free-markets, but these efforts never transcend local boundaries. Global health, population control, and poverty relief initiatives would seem to have more potential for anti-systemic organization, yet more often these communities are coopted 
and dominated by systemic interests that continue to promote free market capitalism and Enlightenment individualism--liberalism--as an anodyne to Third World challenges.

Consequently, I think that Wallerstein underestimates the potential power of this emerging phenomenon to maintain an ideological hegemony. I think that the free-market utopia offered by US-style libertarianism is beginning to constitute a hegemonic discourse among the most powerful global epistemic communities. Further, laissez-faire rhetoric inspired by libertarian philosophy seems to be increasingly influential in the political discourse of Western democracies (and many non-Western polities as well). I think that liberalism carried to its extreme--libertarianism--can potentially extend the capitalist world system for a long time, and that Wallerstein's account of its death is premature.

\section{Notes}

1. While Harvey himself is not a "regulationist", this terminology seems sufficiently broad so as to include most theoretical conceptions of post-Fordist political economy.

1. Mann describes four types of power networks that overlap one another: ideological, economic, military, and political (Mann, 1986). Epistemic communities would appear to be closest to an ideological form of power network that can interact with all three of the other types of power networks. However, the "ideology" is conceived in a Foucauldian sense as a construction and definition of technocratic discourse.

[Page 257]

Journal of World-Systems Research

1. "Regime" in this sense refers to a complex of formal and informal multi-lateral agreements between states regarding international issue spaces. It might include implicit or explicit principles, norms, rules, or decision-making procedures around which actors' expectations converge (Keeley, 1990: 83). This usage derives from international relations theory, and is distinctly different from the way "regime" is used by the French regulation school. We should also note the difference in the way "regulation" is used in this context. "Regulation" in international relations theory refers to specific policies agreed to by states in order to define, control, or "regulate" international relations. "Regulation" as used by the French regulation school has a much broader meaning, and includes all manner of social/political/economic structures functional to the reproduction of the regime of accumulation (Jessop, 1992:48). In this article, "regime" and "regulation" will 
generally be used in the international relations sense of meaning, unless specifically otherwise noted.

\section{References}

Carnoy, Martin, Manuel Castells, Stephen S. Cohen \& Fernando Henrique Cardoso (1993). The New global economy in the information age: reflections on our changing world. University Park, Pa.: Pennsylvania State University Press.

Drake, W.J., \& K. Nicolaidis (1992). "Ideas, Interests, And Institutionalization - Trade In Services And The Uruguay Round". International Organization, 46(1), 37-100.

Haas, P.M. (1992). "Epistemic Communities And International Policy Coordination - Introduction". International Organization, 46(1), 1-35.

Harvey, David (1990). The condition of postmodernity: an enquiry into the origins of cultural change. Cambridge, Mass.: Blackwell.

Hirst, Paul \& J. Zeitlin (1992). "Flexible Specialization versus PostFordism: Theory, Evidence, and Policy Implications". In Michael Storper \& Allen John Scott (Eds.), Pathways to industrialization and regional development. London, New York: Routledge.

Jessop, Bob (1992). "Fordism and Post-Fordism: a critical reformulation". In Michael Storper \& Allen John Scott (Eds.), Pathways to industrialization and regional development. London, New York: Routledge.

Keeley, James F. (1990). "Toward a Foucauldian analysis of international regimes". International Organization, 44(1), 83-105.

Mann, Michael (1986). The sources of social power. Cambridge [Cambridgeshire], New York: Cambridge University Press.

[Page 258]

Journal of World-Systems Research 